\title{
Android Based Financial Literacy Education for Indonesian Students: A Theoretical Approach
}

\author{
Aan Anisah ${ }^{1 *}$, Suwatno ${ }^{2}$, Eeng Ahman $^{3}$, Disman $^{4}$ \\ ${ }^{1}$ Universitas Swdaya Gunung Jati, Cirebon, Indonesia \\ ${ }^{2,3,4}$ Universitas Pendidikan Indonesia, Bandung, Indonesia \\ *Corresponding author. Email: aananisah@upi.edu
}

\begin{abstract}
This study aims to develop a proposition about the importance of incorporating financial literacy education into the curriculum and financial literacy education development model in the 4.0 revolution era through a theoretical approach. This paper elaborates some of the findings from previous researchers as reference findings and explores financial literacy theory. Qualitative research methods with literature studies conducted to obtain a research reference models to explaining the importance of financial literacy in the school curriculum and a development model in accordance with the 4.0 revolution era. This study also provides support for the financial literacy education must be implemented as early as possible through financial education, formal education and non-formal education and there needs to be full support from the government. Financial literacy education in several countries has been included in the curriculum. The results of the study provide recommendations that research needs to be developed on the development of models, strategies and designs for financial literacy education to determine the validity and effectiveness of financial education, so that financial literacy education can increase knowledge, the ability of students to manage their finances and students can behave wisely.
\end{abstract}

Keywords: Financial literacy, Financial literacy education, Development model.

\section{INTRODUCTION}

Education about the importance of Financial Literacy for the people of Indonesia needs to be improved continuously. This educational activity aims to make the community able to manage their finances intelligently and be able to prepare for the future of themselves, their families towards a healthy and financially intelligent society. Financial freedom can be achieved by doing good habits in managing personal finances well, starting from financial planning, using money as well as possible and careful in consumption and saving. Financial difficulties can also arise if there are mistakes in financial management or individual financial management such as mistakes in using credit, lack of financial planning.

Judging from the importance of in-depth knowledge and understanding of financial literacy in the community, making financial literacy education must be done and carried out as early as possible, such as carrying out financial planning habits, using money wisely and evaluating revenues and expenditures, so that these habits become habituations which in the end can influence financial behavior and decision making. In Indonesia, financial literacy education is still very rarely mobilized and implemented, both in the scope of families, schools, the provision of education about financial literacy is still not done seriously and planned.

World Bank survey results show that Indonesia's financial literacy rate is only $20 \%$. This is lower compared to ASEAN countries such as the Philippines $27 \%$, Malaysia $66 \%$ Thailand $73 \%$ and Singapore by 98 [1], and the Indonesian Financial Services Authority (OJK) show "Millennial financial literacy rates are still low age 18-25th level of financial literacy $32.1 \%, 25$ 35th level of financial literacy 33.5\% " [2] means that based on the phenomenon it can be illustrated that adolescents in general are still unable to regulate patterns and own lifestyle because of the high level of consumption that causes them to be irrational in buying their needs.

Some of the surveys above show the low literacy or financial understanding of the Indonesian people. Financial literacy itself is influenced by several factors. Financial literacy shows a financial understanding of 
general knowledge of finance, investment, savings, and insurance [3]. While Margaretha and Pambudhi [4] found the influence of gender, GPA and parents' income on financial literacy. While Calvin [5] said the perception of financial literacy, gender and academic ability affect the financial literacy of students. Whereas Rakow [6] financial education interventions have higher effectiveness compared to classes that have not included financial education in the curriculum. Research conducted by Chen and Volpe [3], found that the level of financial literacy in students aged 18-20 years had low financial literacy. Different results were stated by Taft, Hosein and Mehrizi [7], in their research which stated that age and financial literacy had a positive relationship. While Kim, Gutter, \& Spangler [8] in his research stated that financial education has a significant positive effect on knowledge, attitudes and financial behavior. Strengthened by research conducted by Slamet, et al [9] which states that financial management education significantly influences financial literacy. In his research which states that age and financial literacy have a positive relationship.

Refers to the results of the study, it can be concluded that financial literacy education has a significant role in the process of forming financial literacy in students. As for the implementation of financial literacy education to students, it can be done with a variety of development models in the current digital era, where the role of digital information is very large in shifting the consumption patterns of most people in Indonesia, including among students. Existing facilities on a smartphone or android make it easy for students to meet all their needs easily, ranging from the needs related to lecture material, to the complementary items they need, such as clothing, accessories, and so forth.

Refers to the phenomena that have been described, showing the gap between expectations and reality or phenomena gap. Where based on the theory of "General Theory" from John Maynard Keynes states that humans are naturally based on average, to increase consumption when their income rises, but not as much as an increase in their income. "This means that when people receive extra dollars (money) they are usually used to consume some and save some." $[10,11]$. But the reality happens, students or students spend more or spend money on things that are satisfying desires such as spending money to meet complementary needs such as shopping, traveling rather than saving.

Based on the phenomenon and some of the research results above, the authors are interested in studying the importance of financial literacy education to build personal financial management of students in the era of industrial innovation 4.0. Students live in diverse and complex economic environments so increasing the need for financial literacy education is needed to be able to make financial decisions wisely. With the facilities available on smartphones/androids owned by students, it is necessary to further study about android-based financial literacy education.

\subsection{Financial literacy}

Financial literacy is a must for every individual to avoid financial problems because individuals are often faced with the problem of tradeoffs, a situation where someone has to sacrifice one interest for the sake of other interests. Education and literacy have an important role for the progress of the younger generation who will later develop a country. An educated nation is a nation that prioritizes a culture of reading and writing, because all existing problems can be overcome if the insight and knowledge possessed are very broad. Literacy is the ability to read and understand more in changing social situations and practices, both written and oral, because of the development of information technology and the media, so that it can give birth to new thoughts (ideas). $[12,13]$. The concept of financial literacy is knowledge and understanding of financial concepts so that they are able to make wise and effective financial decisions $[14,15]$.

All the concepts of financial literacy provide an individual's understanding of the use of finance efficiently and effectively, where there is a part to save, invest, also for consumption activities. Financial literacy can be interpreted as financial knowledge, which aims to achieve prosperity [16]. Or it could also be said that financial literacy describes a person's level of competence in managing his personal finances. While Huston [17, 18] defined financial literacy as the ability of an individual to read, analyze, manage, and communicate personal financial knowledge wisely in carrying out economic activities, especially consumption aimed at achieving personal well-being.

\subsection{Financial literacy education}

Financial literacy education is very beneficial for human life, in many cases, accuracy in financial decision making has a significant effect on human wellbeing in the future. Financial literacy education as the ability to read, analyze, manage, and communicate about personal financial conditions that can affect material well-being $[19,20]$. While OECD [21] financial education is defined as the process of building and improving the ability and understanding of consumers and investors about financial products and concepts through information, instructions and advice to develop skills and confidence and awareness of financial risks and increase opportunities for decision making smart and wise finance, able to make alternative actions and know where to ask for financial assistance in order to improve their welfare. In its implementation of financial literacy education can use the android facility, where in this digital era, almost all students have an android, so with this android-based financial 
literacy education, learning is expected to take place anywhere and anytime without being limited by space and time.

\subsection{Android based learning}

Android application-based learning media is something new in the world of education, this learning media is usually already in the form of an educational application or application that contains learning materials and materials. The application product can be downloaded on smartphones and gadgets that have an Android operating system, usually already available on Google Play or Play Store. The use of smartphones through the Android application in learning will provide a new experience for students and make it easier for students to learn, because of its simple form of broad access so that smartpohone is easy to use anytime and anywhere. The use of android applications as learning media must meet some criteria. Thorn in the book [22], put forward six criteria to assess interactive multimedia, namely: 1) Ease of navigation, meaning that a media program must be designed as simple, neat, and as beautiful as possible 2) There is a content of cognition, 3) Knowledge and presentation of information. 4) Media integration, i.e. the media must be able to integrate aspects of the learning objectives, the material that must be learned, the method means the variation of the methods used and the learner's ability. 5) To attract learners' interest, media programs must study artistic appearance and not to forget aesthetics are also criteria 6) Overall function, meaning that the program developed must provide the learning desired by the learner, so that when he finishes running a program (learning) he will feel that he has learned something comfortable and enjoyable.

In a good financial literacy education student are expected to be able to manage their personal finances well. High consumptive attitudes among students and digital information lately, causing financial management to be something that is not young. If the young generation does not yet have the knowledge of financial literacy, then they cannot plan and control the use of money to achieve their individual goals. Agree with Giltman [23], personal financial management is the art and science of managing financial resources from individual units. Furthermore, in managing personal finances there are four domains.

The four domains, namely the use of funds, determining the source of funds, risk management and future planning [24]. With future planning, then you can analyze any needs in the future, so you can prepare investments from now. Income is money you receive for work or from investments [25]. Decisions you make now will affect the income you will earn for the rest of your life.

\section{METHOD}

This study uses a qualitative method, which aims to provide a conceptual mapping of the importance of incorporating financial literacy education into the curriculum and creative and innovative financial literacy education development models in the era of the industrial revolution 4.0. Data collection techniques in this study used a literature survey. Thus, the data in this study came from the research library. The technique taken in this study is in line with the opinion of Bordens $\&$ Abbot [26], that a literature survey is the process of placing, obtaining, reading, and evaluating the research literature. Financial literacy tends to be studied extensively, however, financial literacy education included in the school curriculum, especially in Indonesia, is still limited to literature, especially related to the financial literacy development model in accordance with the demands of the 4.0 revolution. This paper elaborates some of the study describe several reference findings, previous researchers found and explored these findings to provide a conceptual mapping of the importance of including financial literacy education in the school curriculum in Indonesia and a model for developing financial literacy education in accordance with the demands of the 4.0 revolution.

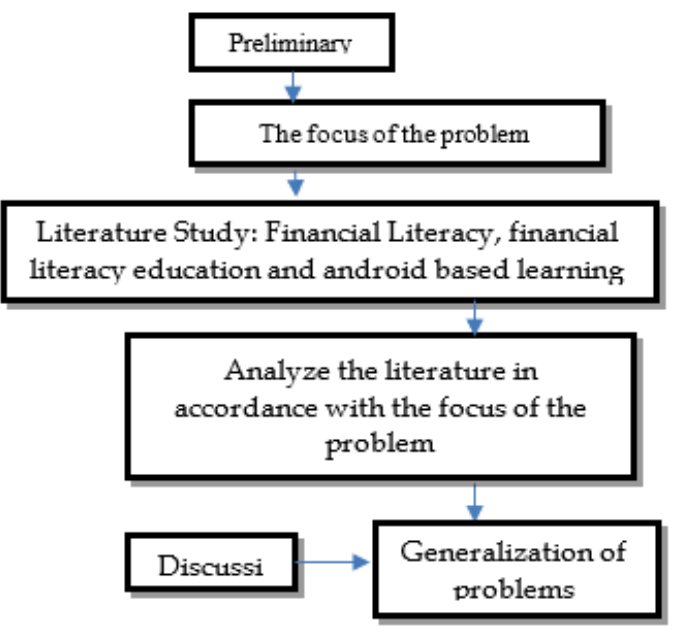

Figure 1. Chronology literature studies of Education financial literacy based on android

In this research, there are five stages, preliminary studies, inventory of ideas and thoughts conducted by reading scientific articles relating to financial literacy education. Second, from the preliminary study, then we determine the focus of the research. Second, collect various kinds of references that are relevant to the research focus. References in the form of books and scientific articles relating to the focus of the research. Third, analyze various kinds of literature and relate it to the focus of research. Fourth understanding of concepts related to a particular research focus or solution. Fifth, generalization of problems, solutions and implications. 


\section{RESULTS AND DISCUSSION}

\subsection{The Importance of Financial Literacy Education in the Era of the Industrial Revolution 4.0}

Based on Wagner's research results [27], finding that increased literacy will increase the understanding of personal finances specifically in the investment area. Likewise, with research conducted by Kotze and Smith [28] on individual perceptions about financial literacy and the need for financial education, and its implications in individual financial management and in entrepreneurship, the results of the study found that the need for financial education and financial literacy in South Africa, to enhance creativity and innovation in entrepreneurship. Financial literacy competence can help students become more financially intelligent and more productive at their life [29].

Referring to the results of research and literature review can be explained that financial literacy education has an important role in providing knowledge and understanding of financial literacy to students, besides that students also understand financial market products, in order to make informed choices. Financial education is adapted to technological developments, and learning of the revolutionary era 40. E-financial literacy education must be given to students, where students are in a complex life and economic environment with rapid technological development, social media offering a variety of interesting products and easily obtain it, with financial literacy education will increase knowledge and understanding student literacy, so they will be wiser in spending their money based on priority scale.

Child and Youth Finance International [30] explains that financial literacy education will provide knowledge, skills and confidence in managing personal finances and making wise financial decisions. Providing education about financial literacy will have a positive influence on student financial behavior. Financial literacy education will make students more rational and wiser in making financial decisions [31]. Another opinion also said that individuals who have the knowledge and understanding of good financial literacy will be smarter in managing their personal finances to achieve the prosperity of Dwiastanti [32].

\subsection{Implementation of Android-Based Financial Literacy Education for Students}

Based on the results of a literacy study of financial literacy education activities carried out by the OJK in the form of a financial literacy car (SiMOLEK), the SiMOLEK Program aims to make socialization on financial literacy easier to reach remote areas. a case of Balikpapan, Bandung, Bogor, Cirebon, Denpasar, Jakarta, Makassar, Malang, Manado, Medan, Pekanbaru, Semarang, Solo and Surabaya. The SiMOLEK program is equipped with multimedia equipment with full features. SiMOLEK also provides educational materials, such as leaflets and brochures [33]. Besides that, in Indonesia in providing financial literacy education, the Financial Services Authority (OJK) has collaborated with the Ministry of Education in producing financial literacy education modules for students, especially high school students. The "Let's Save" campaign was carried out by the Financial Services Authority (OJK) together with the Financial Services Industry (IJK) as the Republic of Indonesia Presidential Regulation No. 82 of 2016 concerning the National Financial Inclusion Strategy (SNKI) issued on September 1, 2016. The program aims to provide motivation to the community ranging from early childhood to students to start and love to do savings activities.

While financial literacy education for students there is no program from the Financial Services Authority, based on the OJK survey the level of financial literacy is still low, so there is a need for financial literacy education for students. The following authors can develop the implementation of financial literacy education as follows:

1. Informal

Financial education through financial education in the family environment. Financial literacy education has since been able to foster prudence in children in spending their money and they will be smarter in managing their finances. The results of Basal \& Derman's research [34] show that family education has a big influence on children in the selection of account books. This is confirmed by the results of Ansong \& Gyensare (2012) research that education is positively related to financial literacy [35].

2. Formal

Based on the results of a study by Kozina \& Ponikvar [36], it shows that financial literacy education conducted at the student level provides knowledge to manage finances and decision-making more wisely, encourages attitudes and skills in carrying out daily life, and feelings of confidence in managing personal finances.

3. Non-formal

Non-formal financial education can be done by means of courses on managing personal finances [37]. The courses aim to improve self-quality, financial planning and financial management both short term and long term.

4. The role of government

The role of the government in financial literacy education is carried out by the OJK in collaboration with the Ministry of Education. Referring to some of the literature above, financial literacy education will have a positive impact on financial literacy, whether through formal, informal, non-formal institutions or the role of government. Students will gain new knowledge, abilities and skills in managing their finances. 
The institutions responsible for providing financial literacy education to the public in several countries [32] are available in the following table 1

Financial literacy is linked to arithmetic in the Australian Curriculum and is taught in mathematics, humanities, and social sciences While Sahat [32] In the United Kingdom, Scotland, New Zealand and Northern Ireland the educational framework for financial literacy education was developed by government educational institutions with responsibility for curricula in schools. In Malaysia the financial literacy education learning framework by Bank Negara Malaysia is working with the Ministry of Education and other financial institutions to take a leadership role within the framework of understanding financial literacy. In Japan, financial literacy education is carried out by the Financial Services Information Center Board, which consists of the Bank of Japan and other member organizations, taking a leading role in developing financial education programs.

Opinion supporting that effective financial literacy education included in one curriculum is Rakow [6] the results of his research found that by including financial literacy in some curricula, the results obtained, there was a significant increase in statistical literacy knowledge in the post-survey when compared with scores on pre-survey. Two sections of Intermediate I saw increases of 17.6 and 22.6 percent respectively, and two parts of Intermediate II also saw statistically significant increases of 31.4 percent and 29.0 percent respectively. This supports that incorporating the topic of financial literacy into the curriculum enhances students' basic financial knowledge. Other than that,

Another opinion is Albeerdy \& Gharleghi's study [38] that financial education, financial socialization agents and attitudes towards finance have an influence on financial literacy. Education can be done both consciously and planned by the government to students and students in the existing curriculum. The suitability of existing knowledge will have an impact on this decision. Therefore, the higher the education and the socialization agent that moves to provide knowledge about financial literacy will further increase their knowledge. Even on the other hand, increasing literacy will improve understanding of personal finances specifically the investment area [27].

From some of the results of the study it can be developed that the introduction of financial education to students through formal education and integrated with the applicable curriculum, as well as the supervision and evaluation of the authorities. Financial literacy education for students can be done through integrated learning with courses, and must use effective, creative and innovative learning models as well as productive learning. This is supported by the results of Neti's study [39] that the creative and productive learning model gives freedom to develop creativity and imagination. The results of other studies conducted by Permana,
Anisah, Yopi [40] that web-based teaching materials are effective in increasing student financial literacy, the results showed that classes that use web teaching materials, higher learning outcomes compared to classes not using web teaching materials. On the other hand learning outcomes affect the financial behavior of students.

Financial literacy education development models for students in addition to the web a lot of models and media that can be developed it seems like the theory of Joyce [41] there are 4 groups of learning models namely the model of information processing, social learning models, behavior learning models and models Personnel. In financial literacy education, the writer focuses more on the development model of financial literacy education on android-based students such as the Android-based educative game and Android-based emodule. The reason for learning android-based financial literacy education is in the world of education, for example, almost all students use mobile phones during teaching and learning activities.

One of the media designed in financial literacy education is an educational game with the help of the RPG Maker MV application. The flow of educational game models that can be developed using the drill flowchart model according to Rusman [42] can be seen in the following figure:

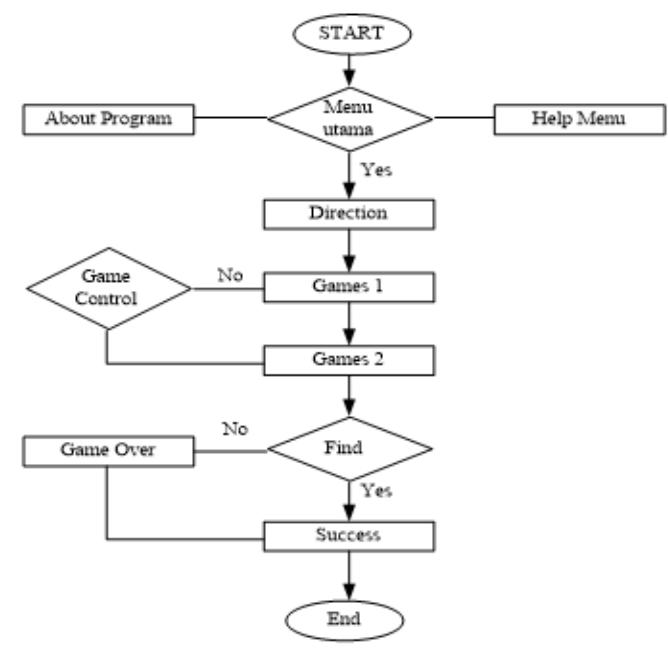

Figure 2. Modified Educational Games Model Flowchart [42]

Information:

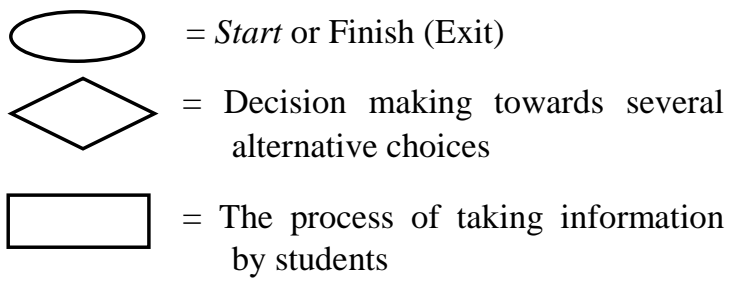


Table 1. Institutions Responsible for Providing Financial Literacy Education In Several Countries

\begin{tabular}{|c|c|c|c|}
\hline Country & Framework & $\begin{array}{c}\text { Date } \\
\text { Published }\end{array}$ & Responsible Institutions \\
\hline Australia & $\begin{array}{l}\text { National Consumer and Financial Literacy } \\
\text { Framework }\end{array}$ & $\begin{array}{l}\text { First published } \\
\text { 2005 Update } \\
2009,2011\end{array}$ & $\begin{array}{l}\text { Ministerial Council for Education, Early } \\
\text { Childhood and Development and Youth } \\
\text { Affairs (MCEEDYA) }\end{array}$ \\
\hline Brazil & $\begin{array}{l}\text { Guidance for Financial Education in } \\
\text { Schools }\end{array}$ & 2009 & $\begin{array}{l}\text { Department of Education at national } \\
\text { and local levels; coordinated by the } \\
\text { Brazilian Security Exchange } \\
\text { Commission (CVM) with the support of } \\
\text { the Central Bank, the Private Pension } \\
\text { Plans Secretary (PREVUC) and the } \\
\text { Insurance Supervisory and Regulatory } \\
\text { Authority (SUSEP) }\end{array}$ \\
\hline England & $\begin{array}{l}\text { Guidance on Financial Capability in the } \\
\text { Secondary Curriculums: Key Stage } 3 \text { and } \\
4\end{array}$ & 2008 & $\begin{array}{l}\text { Department for Children, Schools and } \\
\text { Families }\end{array}$ \\
\hline Japan & Financial Education Program in Schools & 2007 & $\begin{array}{l}\text { Central Council for Financial Services } \\
\text { Information }\end{array}$ \\
\hline Netherlands & $\begin{array}{l}\text { Basic Vision financial education: } \\
\text { curriculum framework for development } \\
\text { and implementation }\end{array}$ & January 2009 & $\begin{array}{l}\text { Center headed by the Dutch Ministry of } \\
\text { Finance }\end{array}$ \\
\hline Malaysia & $\begin{array}{l}\text { Framework of Financial Education for } \\
\text { Malaysian school children under the } \\
\text { school adoption programed }\end{array}$ & 2006 & $\begin{array}{l}\text { Bank Negara Malaysia, in collaboration } \\
\text { with the Ministry of Education and the } \\
\text { financial institutions that participate in } \\
\text { the school's adoption programmed }\end{array}$ \\
\hline
\end{tabular}

The low index of student financial literacy, demands hard work for the world of education in Indonesia, especially for universities. Cooperation between various parties, formal and informal institutions and the government also needs to be improved in the implementation of financial literacy education. At higher education institutions, it is necessary to develop creative and invasive learning designs in financial literacy education that can increase motivation, knowledge and understanding of students about financial literacy, so that educational goals are achieved properly and students can implement them in their personal financial management, android based financial literacy education is one form of financial literacy education development model.

\section{CONCLUSION}

Financial literacy education is a necessity for every country and is a global problem, where financial literacy has a significant effect in increasing the knowledge, understanding of student financial literacy: 1) In Indonesia the level of financial literacy at the students is still relatively low, 2) Financial literacy education in universities plays an important role in the process of forming the understanding and implementation of student financial literacy, 3). Financial literacy education for students must be adjusted to the needs, facilities, culture and technological development, so that financial literacy education will be more effective. 4) Increasing financial literacy for students can be done through the application of financial education, 5). One of the models of financial literacy education development that can be developed is android-based financial literacy education, such as educational games, web or e-module. Economic literacy education is one of the effective education models, where students consider that a smartphone is a necessity for students, so with Android-based education they can learn anywhere and anytime. It is hoped that knowledge and financial literacy skills and they will be wiser in managing their personal finances to make good financial decisions and ultimately achieve individuals' financial well-being Several other parties such as families, non-educational institutions and governments help, guide and direct students in managing finances.

The results of this study are expected to provide understanding to academics in understanding the importance of including financial literacy education into the curriculum and are expected to be material for discussion or reference in conducting further research. In a broader context with a different scope. Meanwhile, in practical terms, the results of this study are expected to provide practitioners with an understanding of the efforts to improve financial literacy through good financial literacy education, so as to build good financial behavior. The results of this study also have implications for MSMEs or companies to strengthen stimuli that can increase existing financial literacy. The stimulus given can be in the form of increasing financial literacy education for business owners or their employees. 


\section{ACKNOWLEDGMENTS}

Acknowledgments are conveyed to:

1. Dr. H. Mukarto Siswoyo, M.Si, Rector of Universitas Swadaya Gunung Jati Cirebon and the provider of research funding,

2. Prof. Dr. H. Abdul Rozak, M.Pd. As Dean of FKIP Universitas Swadaya Gunung Jati Cirebon who always motivates to do research

3. PICEEBA International Conference Committee which has facilitated the publication of authors' research results

4. All parties who have contributed and helped during this research process

Hopefully all the goodness that has been given to the author will be accepted by Allah SWT as an act of worship. Hopefully this scientific work is useful for writers in particular and readers in general.

\section{REFERENCES}

[1] World Bank, "World Development Indicators 2018", [Online]. Tersedia: https://datacatalog.worldbank.org/dataset/worlddevelopment-indicators. [Diakses 3 Maret 2020]

[2] N. Zuraya, "OJK Milenial Masih Belum Melek Berinvestasi dan Berasuransi”, [Online]. Tersedia: https://republika.co.id/berita/px7zxy383/ekonomi /keuangan/19/08/29/pwzups383-ojk-milenialmasih-belum-melek-berinvestasi-dan-berasuransi. [Diakses 3 Maret 2020]

[3] H. Chen, \& R.P. Volpe, "An Analysis of Personal Financial Literacy Among College Students", Financial services review, 7(2), 107-128. 1998.

[4] F. Margaretha, \& R.A Pambudhi, "The level of financial literacy in undergraduate students of the Faculty of Economics", Journal of Management and Entrepreneurship, 17 (1), 76-85. 2015.

[5] J. Calvin, Commentaries of the First Book of Moses Called Genesis. lulu.com. 2018.

[6] K.C Rakow, "Incorporating financial literacy into the accounting curriculum", Accounting Education, 28(4), 384-400, 2019.

[7] M.K, Taft, Z.Z Hosein, S.M.T. Mehrizi, \& A Roshan, "The relation between financial literacy, financial wellbeing and financial concerns". International Journal of Business and Management, 8(11), 63. 2013

[8] J. Kim, M.S. Gutter, \& T. Spangler, "Review of family financial decision making: Suggestions for future research and implications for financial education". Journal of Financial Counseling and Planning, 28(2), 253-267. 2017

[9] A. Slamet, A. Yulianto, S. Ridloah, \& K.B Abiprayu, "Financial Inclusion and Financial Literation for 'Laku Pandai'Customers', KnE Social Sciences, 1-8. 2019.

[10] N.G Mankiw, \& R. Reis, "Sticky information in general equilibrium", Journal of the European Economic Association, 5(2-3), 603-613. 2007

[11] N.M Ngala, \& M.L Mawo, "An Analysis of the Pre- and Post-Harvest Management Techniques in Rice Production: The Case of Unvda Ndop, North West Region, Cameroon", International Journal of Sustainable Agricultural Research, 2(4), 120-132. 2015

[12]A. Capuano, \& I.Y. Ramsay, Multiliteration learning: An answer to the challenges of 21st century education in the Indonesian context. Bandung: PT Refika Aditama. 2015

[13] Irianto \& Febrianti. "What Causes Suboptimal Financial Behaviour? An Exploration of Financial Literacy, Social Influences and Behaviour Economics", Social Science Research Network Electronic Library (540). 2011.

[14] Irianto, P. Oviolanda and L.Y. Febrianti. "Importance of Literacy Mastery for Young Generation in Facing MEA", The 1st International Education and Language Conference Proceedings Center for International Language Development of Unissula (ELIC). 2017

[15] D.L. Remund, "Financial literacy explicated: The case for a clearer definition in an increasingly complex economy", Journal of consumer affairs, 44(2), 276-295. 2010

[16]A.N. Yushita, "The importance of financial literacy for personal financial management. Nominal", Accounting and Management Research Barometer, 6 (1), 11-26. 2017

[17]H. Akmal, \& Y.E Saputra, "Financial Literacy Level Analysis", JEBI (Journal of Islamic Economics and Business), 1 (2), 235-244. 2016

[18] S.F. Putri, J. Widodo, \& S. Martono, "The Effect of Financial Literation Through Rationality to Consumptive Behaviors (Case Study of Class XI Social Sciences Students of State High Schools in Semarang City)", Journal of Economic Education, 5 (2), 179-192. 2016.

[19]S. Rapih, "Financial Literacy Education in Children: Why and How?", Scholaria: Journal of Education and Culture, 6 (2), 14-28. 2016

[20] L. A. Vitt, C. Anderson, J. Kent, D. M Lyter, J.K. Siegenthaler, \& J. Ward, "Personal Finance and 
The Rush To Competence: Financial Literacy Education In The U.S. Middleburg, VA: Fannie Mae Foundation. 2020

[21] OECD, Oslo Manual: Proposed Guidelines for Collecting and Interpreting Technological Innovation Data. Paris. 2005.

[22] K.S. Bordens, \& B.B. Abbott, Research design and method, 6th ed, USA: McGraw-Hill. 2005

[23] J. Wagner, "An analysis of the effects of financial education on financial literacy and financial behaviors", 2015

[24]H.H. Sanaky, Interactive-Innovative Learning Media. Yogyakarta: Kaukaba Dipantara. 2013

[25]R.A Nggili, Personal financial management at PDSPK level 1 training GMKI. Salatiga : Menonite Training Center. 2012

[26] N. Hamidan, \& S. Dashti, "Risk Assessment of Oil Reservoirs of Amout-E-Arvand Free Zone Area at the Explotiation Phase Using FMEA Method". Journal of Health, 9(4), 389-402. 2018

[27] R. Jain, "An analysis of income and investment pattern of working women in the city of Ahmedabad", International Journal of Research in Management \& Technology (IJRMT), 4(6). 2016

[28]L. Kotze, A. Smit, "Personal Financial Literacy and Personal Debt Management: The Potential Relationship with New Venture Creation", SAJESBM, 1(1): 35-50. 2008

[29]D.S. Puspitarona, "Financial Literacy for Elementary School Students: Case Study of Bandung City Indonesia”, International Journal of Learning, Teaching and Educational Research, Vol. 18 No. 10. 2019

[30] Child and Youth Finance International (CYFI), Training Course on: Fostering National Financial Education Strategies. Podgorica: CYFI and GIZ. 2016.

https://journals.sagepub.com/doi/10.1177/204717 3417719555

[31]B. Fraczek, \& M. Klimontowicz, M. "Financial literacy and its influence on young customers' decision factors", Journal of Innovation Management, 3(1), 62-84. 2015

[32] H.S. Renol HS, M. Indriayu, "Financial Literacy Study on High School Students", Proceedings of the National Seminar on Economic and Business Education, Solo State University. Vol 3, No. 1. 2017.

[33] S.R.D. Setiawan, "Perluas Literasi Keuangan, OJK Jalin Kerja Sama dengan Muhammadiyah". [Online].

Tersedia: https://money.kompas.com/read/2017/04/18/1805 20926/perluas.literasi.keuangan.ojk.jalin.kerja.sa ma.dengan.muhammadiyah [Diakses Desember 2020].

[34]H.A Başal, \& M.T Derman, "Opinions and Activities of Families Regarding Money Management and Saving Awareness", Journal of Human Sciences, 13(1), 957-964. 2016

[35] A. Ansong, \& M.A. Gyensare, "Determinants of university working-students' financial literacy at the University of Cape Coast, Ghana", International Journal of Business and Management, 7(9), 126. 2012

[36]F.L. Kozina, \& N. Ponikvar, "Financial Literacy of First-Year University Students: The Role of Educational", International Journal of Management, Knowledge and Learning. Vol 4 (2) pp. 241-255. 2015

[37] A. Izekenova, A \& Z. Temirbekova, "Innovation in the higher economy and finance education: developing a new course of Social security and pension provision", Procedia-Social and Behavioral Sciences, 122, 510-514. 2014

[38] M.I. Albeerdy, \& B. Gharleghi, (2015). "Determinants of The Financial Literacy among College Students in Malaysia", International Journal of Business Administration, 6(3), 15-24. 2015

[39] N. Budiwati, Model Kreatif dan Inovatif dalam Bidang Ekonomi. 2010

[40] D.P. Putri, A. Anisah, N. Yopi, Yuniningsih, "Analisis Literasi Keuangan dan Lingkungan Melalui Pembelajaran Berbasis Web Terhadap Perilaku Konsumsi Mahasiswa", Jurnal PROMOSI. Jurnal Pendidikan Ekonomi UM Metro Vol.7. No.2. 2019

[41] B. Joyce, dkk, Models of Theaching, Yogyakarta: Pustaka Pelajar. 2016

[42] Rusman, Pembelajaran Tematik Terpadu Teori, Praktik dan Penilaian. Jakarta : 2015. 